\title{
Effect of Chitosaccharides in Nodulation and Growth in Vitro of Inoculated Soybean
}

\author{
Daimy Costales¹, Alejandro Bernardo Falcón', María Caridad Nápoles', \\ Julien de Winter ${ }^{2}$, Pascal Gerbaux ${ }^{2}$, Robertus Cornelis Adrianus Onderwater ${ }^{3}$, \\ Ruddy Wattiez ${ }^{4}$, Juan Carlos Cabrera ${ }^{3 *}$ \\ ${ }^{1}$ Grupo de Productos Bioactivos, Departamento de Fisiología y Bioquímica Vegetal, Instituto Nacional de \\ Ciencias Agrícolas (INCA), San José de las Lajas, Cuba \\ ${ }^{2}$ Interdisciplinary Center for Mass Spectrometry, Organic Synthesis and Mass Spectrometry Laboratory, \\ University of Mons Unité Biotechnologie, Ghislenghiem, Belgium \\ ${ }^{3}$ Unité Biotechnologie, Materia Nova ASBL, Ghislenghien, Belgium \\ ${ }^{4}$ Biosciences Research Institute, Department of Proteomics and Microbiology, University of Mons-UMONS, \\ Mons, Belgium \\ Email: daimy@inca.edu.cu, alfalcon@inca.edu.cu, tere@inca.edu.cu, julien.dewinter@umons.ac.be, \\ Pascal.GERBAUX@umons.ac.be, Rob.Onderwater@MATERIANOVA.BE, ruddy.wattiez@umons.ac.be, \\ "Juan-Carlos.Cabrera@materianova.be
}

Received 25 May 2016; accepted 18 July 2016; published 21 July 2016

Copyright (C) 2016 by authors and Scientific Research Publishing Inc. This work is licensed under the Creative Commons Attribution International License (CC BY). http://creativecommons.org/licenses/by/4.0/

(c) (i) Open Access

\section{Abstract}

The influence of chitosaccharides on the symbiotic interaction between Bradyrhizobium and soybean was examined. The results show that chitosaccharides either positively or negatively affect soybean nodulation or plant growth depending on their molecular weight, concentration and the application methods. When directly added to the in vitro culture media, chitosan of high molecular weight inhibit Bradyrhizobium viability in a dose dependent manner while chitooligosaccharides reduce slightly the bacteria viability only at concentration equal or higher than $50 \mathrm{mg} \cdot \mathrm{L}^{-1}$. Chitooligosaccharides significantly enhance nodule formation and dry mass in soybean roots at doses between 10 and $100 \mathrm{mg} \cdot \mathrm{L}^{-1}$. Both types of chitosaccharides, at the highest doses $\left(>500 \mathrm{mg} \cdot \mathrm{L}^{-1}\right)$, negatively affect plant height and root size, whereas medium doses (50 to $100 \mathrm{mg} \cdot \mathrm{L}^{-1}$ ) increase slightly leave number. Under field conditions, foliar application of both chitosaccharides enhances growth and nodulation of soybean plants. Nevertheless, using this application method, chitosan remains more effective than chitooligosaccharides.

\section{Keywords}

Chitosan, Glycine max, Bradyrhizobium, Antimicrobial

\footnotetext{
${ }^{*}$ Corresponding author.
}

How to cite this paper: Costales, D., Falcón, A.B., Nápoles, M.C., de Winter, J., Gerbaux, P., Onderwater, R.C.A., Wattiez, R. and Cabrera, J.C. (2016) Effect of Chitosaccharides in Nodulation and Growth in Vitro of Inoculated Soybean. American Journal of Plant Sciences, 7, 1380-1391. http://dx.doi.org/10.4236/ajps.2016.79131 


\section{Introduction}

The increasing cost of fertilizers and their negative impact on the environment have forced people to look for other possible sources of plant nutrients. In this context, biological nitrogen fixation (BNF) by plants is nowadays considered to be one of the most important phenomena occurring in nature, after photosynthesis [1]. However, the ability to utilize atmospheric nitrogen is restricted to a few groups of prokaryotes that are able to convert atmospheric nitrogen to ammonia. The association between the diazotrophic group rhizobia and plants belonging to legume (Fabaceae) family is the most studied and well characterized symbiosis [2]. This symbiotic relationship between legumes and rhizobia represents the most important nitrogen-fixation association in the world, with an annual production of approximately 200 million tons of nitrogen [3]. Optimizing this symbiosis can increase crop yields and enhance soil fertility, reducing the negative environmental impacts associated with nitrogen fertilizer use [4] [5].

The gram-negative soil bacterium Bradyrhizobium is involved in an efficient symbiotic relationship with soybean seed and root exudates being demonstrated to be potent chemo attractants for the bacterium [6]. Also the symbiosis supplies almost all the nitrogen required by the culture [3], even if soybean is highly nitrogendemanding for optimal development and grain productivity [7] [8]. Inoculation with the appropriate rhizobia bacteria provides high numbers of viable effective rhizobia to the rhizosphere allowing rapid soybean colonization and nodulation [9].

Chitosan is the deacetylated (water soluble) form of chitin, a major structural polysaccharide of fungal cell walls and crustacean exoskeletons. Chitosan is the overall name of a group of heteropolysaccharides of $\beta$-1-4 linked D-glucosamine and N-acetyl D-glucosamine residues differing in structure, molecular weight (MW) and degree of acetylation (DA), and properties such as pKa, solubility, viscosity... [10] [11]. Commonly, the term “chitosan" stands for the high molecular weight forms, whereas chitooligosaccharide (COS) concerns the low molecular weight chitosan oligosaccharides (degree of polymerization, i.e. number of monosaccharide residues, lower than 15). Primarily, the term "chitosaccharides" is used to denote chitosan as well as COS.

The peculiar physical and chemical properties (water solubility, polycation nature, protein and metal binding affinities, biocompatibility) and its wide biological activities render chitosaccharides ubiquitous components in plant biostimulants. Chitosaccharides are powerful activators of various plant defence responses inducing resistance against pathogenic diseases [11] [12].

Chitosaccharides also play an inhibiting role for the growth and development of numerous plant pathogens, including fungi, oomycetes and bacteria [12]-[14]. They have also demonstrated to intervene as regulators in plant growth and development, ultimately increasing crop production [15].

The chitosaccharide structure-dependence on the induction of plant resistance and on its antimicrobial activities has been widely studied [10] [12]. However, less information are available regarding the influence of these structural features on the modification of plant growth and development. In addition, all those biological responses also depend on the concentrations and application form of these compounds [12].

Curiously, some chitosaccharide compounds are also involved in plant-microorganism symbiosis. Indeed, some soil inhabiting bacteria of Rhizobiaceae family, stimulated by legume flavonoids, release per acetylated chitosaccharides, called nodulation factors (NF's), inducing nodule formation on certain particular legume roots [16]. Bacteria, present inside those symbiotic nodules, will reduce atmospheric nitrogen producing ammonia. NF's were demonstrated to play several critical roles for the success of the symbiotic process [17] by stimulating the cell division morphogenesis of the legume root system and inducing the transduction of the signal leading to the nodule formation [18]. Chitin oligosaccharides are indeed recognized by receptors on plasma membrane of the plant cells [19] and induce cortical cell divisions of the root leading to formation of the nodule primordium [20].

While the effect of chitosaccharides on numerous plant-pathogen interactions has been extensively studied, less known is the impact of exogenously applied chitosaccharides on plant-microorganism symbiosis. In particular, in our study, the influence of chitosaccharide molecular weight (MW) on the Bradyrhizobium-soybean symbiotic interaction is examined. Chitosaccharides were directly added in the culture medium of Bradyrhizobium, in the in vitro culture medium soybean seedlings inoculated with Bradyrhizobium and were also foliar sprayed on soybean plants in field trials. The nodulation efficiency as well as the growth of soybean plants was measured to establish the influence of chitosaccharide structure on the symbiotic activity. 


\section{Materials and Methods}

\subsection{Preparation of Chitosaccharides}

Two chitosan derivatives were prepared from a chitin polymer obtained, in turn, from lobster (Panulinus argus) exoskeleton: A chitosan polymer and chitooligosaccharides prepared by enzymatic hydrolysis of the polymer [12] [21].

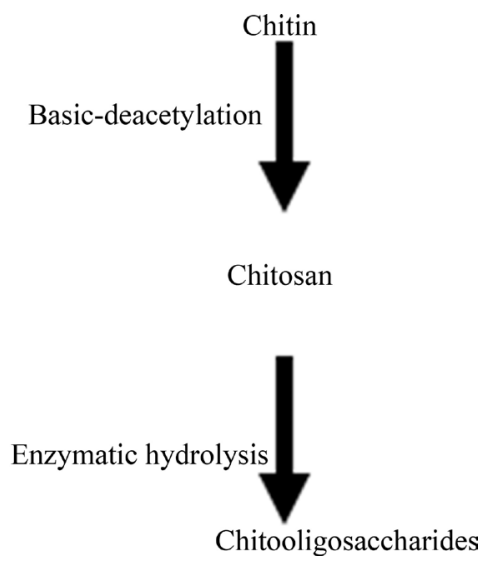

\subsubsection{Determination of Molecular Weight and Degree of Acetylation}

The potentiometric determination of the degree of acetylation was carried out following the method given by [22]. The viscosity average molecular weight $\left(M_{v}\right)$ determination of chitosan was performed using an Ubbelohde capillary viscometer $(\varnothing=0.5 \mathrm{~mm})$ at $25^{\circ} \mathrm{C}$. The solvent was $0.3 \mathrm{M}$ acetic acid $/ 0.2 \mathrm{M}$ sodium acetate which does not form aggregates in this mixture and the average viscometric molecular weight was calculated using the Mark-Houwink equation $\left([\mathrm{g}]=\mathrm{KM}^{\mathrm{a}}\right.$, where $[\mathrm{y}]$ is the intrinsic viscosity and $\mathrm{M}$ the molecular weight. The $\mathrm{K}$ $\left(\mathrm{mL} \cdot \mathrm{g}^{-1}\right)$ and parameters at $25^{\circ} \mathrm{C}$ are $7.9 \times 10^{-2}$ and 0.796 respectively [23].

\subsubsection{Size Exclusion Chromatography (SEC) Analysis}

SEC analyses are carried out using a TSKgelG4000SWXL column $(7.8 \times 300 \mathrm{~mm}$, TOSOH Co. $)$ with a VISCOTEK size exclusion chromatograph and monitored using a VISCOTEK TDA302 triple detector array in the viscometer mode. The column is eluted with $0.3 \mathrm{M}$ acetic acid containing $0.2 \mathrm{M}$ sodium acetate at $35^{\circ} \mathrm{C}$, at $0.6 \mathrm{~mL} / \mathrm{min}$ flow rate. Before injection, the samples are filtered through Sartorius filters $(0.45 \mu \mathrm{m})$.

\subsubsection{Thermogravimetric Analyses}

Thermogravimetric analyses (Thermo-gravimetric analyser, TGAQ500, TA-instruments) are used to examine the thermal properties of COS and chitosan. Analyses are performed using $\sim 5 \mathrm{mg}$ powder sample and performed in a nitrogen gas atmosphere in platinum crucibles. The scanning rate is $20^{\circ} \mathrm{C} \cdot \mathrm{min}^{-1}$, from room temperature to $600^{\circ} \mathrm{C}$.

\subsubsection{Mass Spectrometry Analyses of Chitooligosaccharides}

MALDI-TOF mass spectra are recorded using a Waters QTOF Premier mass spectrometer (UMONS) equipped with a nitrogen laser, operating at $337 \mathrm{~nm}$ with a maximum output of $500 \mathrm{~J} \cdot \mathrm{m}^{-2}$ delivered to the sample in $4 \mathrm{~ns}$ pulses at $20 \mathrm{~Hz}$ repeating rate. Time-of-flight mass analyses are performed in the reflectron mode at a resolution of about 10,000. The COS samples are analyzed using a mixture between dihydroxybenzoic acid and dimethylaniline as an ionic liquid matrix (DHB/DMA).This matrix is prepared by dissolving $25 \mathrm{mg}$ of DHB in $250 \mu \mathrm{L}$ acetonitrile: water (1:1) and adding $5 \mu \mathrm{L}$ of DMA. The matrix solution $(1 \mu \mathrm{L})$ is applied to a stainless steel target and air dried. COS samples are dissolved in water to afford $1 \mathrm{mg} \cdot \mathrm{mL}^{-1}$ solutions. $1 \mu \mathrm{L}$ aliquots of those solutions are applied onto the target area already bearing the matrix crystals, and air-dried before adding $1 \mu \mathrm{L}$ of NaI solution (2 $\mathrm{mg} \cdot \mathrm{mL}^{-1}$, acetonitrile: water, 1:1). For the recording of the single-stage MS spectra, the ions are transmitted into the pusher region of the time-of-flight analyzer where they are mass analyzed with $1 \mathrm{~s}$ integration time. Data are acquired in continuum mode until acceptable averaged data are obtained. 


\subsection{Bioassays}

\subsubsection{Effect of Chitosaccharides on Bradyrhizobium elkanii Viability}

Yeast extracted-manitol agar (YEM) media is amended with different volumes of each chitosaccharide samples, chitosan and COS, to reach the following final concentrations: $1,10,50,100,500,1000 \mathrm{mg} \cdot \mathrm{L}^{-1}$. The $\mathrm{pH}$ is then adjusted and all solutions are autoclaved at $120^{\circ} \mathrm{C}$ and $152 \mathrm{kPa}$, for 20 minutes. $20 \mathrm{~mL}$ of the sterile solutions are deposited, at room temperature, into Petri dishes. Every dish (5 per treatment) is inoculated by dissemination of $100 \mu \mathrm{L}$ of a B. elkanii [6] liquid culture at the concentration of $1.22 \times 10^{9}$ units forming colonies (CFU) per mL (Strain ICA 8001). Dishes are incubated at $30^{\circ} \mathrm{C}$ during 10 days. After incubation, the number of $\mathrm{CFU} \cdot \mathrm{mL}^{-1}$ is measured in every dish and the percentage of inhibitory activity is calculated using the formula IA $=[(\mathrm{C}-\mathrm{T}) / \mathrm{C}] \times$ 100 , where $\mathrm{C}$ is the number of colonies in the control and $\mathrm{T}$ is the number of colonies for the corresponding chitosan treatment.

\subsubsection{Effect of Adding Chitosaccharides in the Culture Media of Soybean Plantlets}

Soybean plantlets are growth from seeds (Cuban variety INCAsoy-27 [24] previously disinfected with ethanol (75\%) and sodium hypochlorite (2.5\%) for 5 minutes and rinsed six times with sterile distillated water. Seeds are germinated in Petri dishes containing water-agar (0.75\%) for 3 days at $30^{\circ} \mathrm{C}$ in the dark. Once germinated (15 $20 \mathrm{~mm}$ of root length), seeds - one seed per tube-are placed in glass tubes containing semisolid culture media and the chitosaccharides samples $\left(1,10,50,100,500\right.$ and $\left.1000 \mathrm{mg} \cdot \mathrm{L}^{-1}\right)$. After 7 days, plantlet roots are carefully inoculated with $1 \mathrm{~mL}$ of a Bradyrhizobium elkanii (ICA 8001 strain) culture at the concentration of $10^{9}$ colony-forming units per $\mathrm{mL}\left(\mathrm{CFU} \cdot \mathrm{mL}^{-1}\right)$, grown in YEM liquid medium. Plantlets are cultivated during 37 days in a growth chamber under controlled conditions: light/dark sequences $\left(16 / 8\right.$ hours), temperature $\left(25^{\circ} \mathrm{C}\right)$ and humidity (70\%) [25].

Several nodulation variables, i.e. total number of nodules by plant, percentage of nodular effectiveness (by visualizing internal color of nodules) and dry nodular mass (g), are determined in 20 plantlets per treatment at 30 days after inoculation with $B$. elkanii. In addition, growth variables such as the number of trifoliate leaves, the height $(\mathrm{cm})$ and the root length $(\mathrm{cm})$ per plant, are determined after 30 days after inoculation (dai) with B. elkanii in 20 inoculated plantlets per treatment.

A completely randomized design is used in the experiment and the assay is performed in duplicates. Data are analyzed through a simple ANOVA method with the statistical program Statgraphics Plus 5.1 for Windows $@$. Means with the same letters did not differ for $\mathrm{p} \leq 0.05$ in the Tukey HSD Test.

\subsubsection{Effect of Chitosaccharides Foliar Sprayed on Soybean Plant Growth and Yield under Field Conditions}

The experiments was conducted during March and May 2012 on one experimental site at the National Institute Agricultural Science ( $\left.23^{\circ} 00^{\prime} \mathrm{N}, 81^{\circ} 12^{\prime} \mathrm{OE}, 138 \mathrm{mamsl}\right)$, sited in $3_{1 / 2} \mathrm{~km}$ of Tapaste main road, Mayabeque, Cuba. The soil of the experiment was Udic Haplustalf having total nitrogen $0.06 \%$, organic matter $3.33 \%$, available phosphorus $22.7 \mathrm{ppm}$, exchangeable potassium 0.2 meq\%, carbon content of $2 \%$ and $\mathrm{pH} 7.0$. The soil used was characterized by a neutral $\mathrm{pH}$ which is suitable for crop development and the establishment of the population of Bradyrhizobium. The content of organic matter, total nitrogen and carbon content is low, while assimilable phosphorus levels are high.

Soybean plants of the INCAsoy27 are grown from seeds, inoculated with Bradyrhizobium elkanii $\left(2.5 \times 10^{8}\right.$ $\mathrm{CFU} \cdot \mathrm{mL}^{-1}$ ) before planting in pots capacity of $1.5 \mathrm{~m}^{2}$. Plants are cultivated with the average daily temperatures ranged from $19^{\circ} \mathrm{C}$ to $30^{\circ} \mathrm{C}$, while humidity and precipitation were also recorded with stockings that were in the range of 50\% to $92 \%$ and $1.92 \mathrm{~mm}$, respectively. Twice, at growing (V2 face) and flowering (R2 face) periods, plants are sprayed with chitosan or COS samples with 75 and $750 \mu \mathrm{g}$ per plant, respectively, with the use of a backpack (16 L). It is used as a treatment, inoculated with B. elkanii but without foliar application of chitosan plants. Intercultural and phytosanitary control operations such as irrigation, weeding and pest were followed during the evaluation period.

Twenty mature plants on production per treatment are used to measure nodulation (number and dry mass of nodules) and growth (height, leaves number, dry mass of aerial part). Some components of the yield (number of pods containing seeds per plant) were also evaluated, to 10 plants for blocks of each treatment). The experiment is performed as a random blocks design of four blocks conformed by twenty plants each one in each treatment 
and planting distance between plants of $0.075 \mathrm{~m}$ and between rows of $0.75 \mathrm{~m}$, and repeated twice. Data are analyzed with ANOVA $(\mathrm{p} \leq 0.05)$ and means are compared by using the Duncan Multiple Rank Test.

\section{Results}

\subsection{Chitosacharide Characterization}

For the present study, we thus intend to investigate the influence of the chitosaccharide structure on the symbiotic relationship between Bradyrhizobium and soybean. In particular, one of the most determining structural parameter is the molecular weight or the average molecular weight of the chitosaccharide. In this context, two different chitosaccharide samples, i.e. a chitosan polymer and a chitooligosaccharide (COS) mixture, have been selected and prepared following the step sequence chitin/chitosan/COS. Indeed, the chitosan polymer is readily prepared by deacetylation of chitin. Consecutively, the so prepared and characterized chitosan is submitted to enzymatic hydrolysis to afford the COS mixture, see experimental section. The average molecular weights as well as the degree of acetylation of both the chitosan and the COS mixtures are then measured and presented in Table 1.

As determined by viscometry and confirmed by SEC Figure 1(a), the MW of the chitosan polymer and the COS mixture are then estimated to amount to 130,000 and $1200 \mathrm{~g} \cdot \mathrm{mol}^{-1}$, respectively. The complete disappearance of the chitosan trace when eluting the COS mixture also confirms the quantitative nature of the enzymatic hydrolysis procedure. Interestingly, whereas the degree of acetylation of the prepared chitosan polymer is measured at $12 \%$, confirming then that chitosan is efficiently prepared for the starting chitin sample; no-residual acetylated groups remained longer detectable on the COS. The production of shorter chitosaccharide chains is also clearly demonstrated by comparing the important decrease of the intrinsic viscosity of solutions in acetic acid when passing from chitosan to COS (Table 1).

Since the thermal properties of chitosan are also dependent on their molecular weight [26] [27], thermogravimetric analysis (TGA) can also be used to quickly validate molecular weight differences. As presented in Figure 1(b), thermal degradation of both samples is clearly occurring at different temperatures, $232^{\circ} \mathrm{C}$ and $287^{\circ} \mathrm{C}$ for $\mathrm{COS}$ and chitosan, respectively. Also, it is important to note that only one major peak in the TG curves is observed for both chitosan and COS. This first definitively demonstrate the quantitative conversion of the chitosan polymer to shorter chains and could also indicate that the thermal degradation of chitosacharides is a simple one-step reaction.

In order to get more accurate data on the nature of the COS mixture, mass spectrometry analyses were then

Table 1. Molecular weight, viscosity and degree of acetylation of chitosan and COS.

\begin{tabular}{|c|c|c|c|}
\hline & Molecular weight $\left(\times 10^{-3}\right)$ & Intrinsic viscosity $\left(\mathrm{dL} \cdot \mathrm{g}^{-1}\right)$ & Degree of acetylation (\%) \\
\hline Chitosan & 130 & 5.87 & 12 \\
\hline $\cos$ & 1.2 & 0.18 & 0 \\
\hline
\end{tabular}

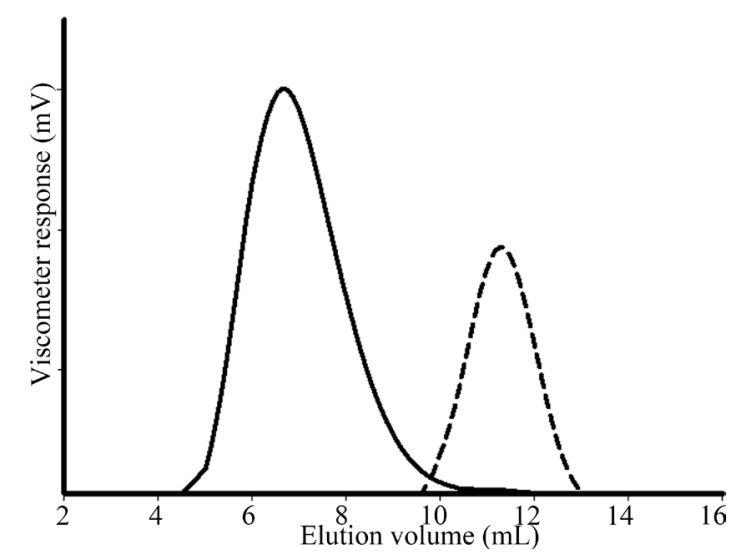

(a)

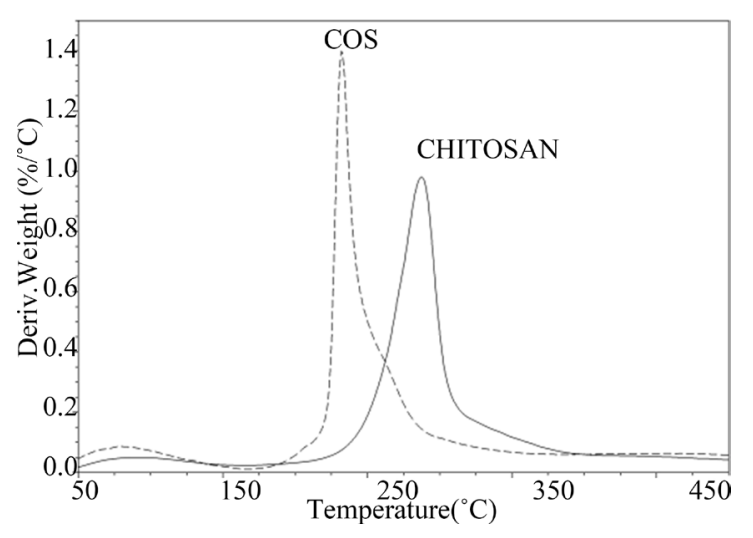

(b)

Figure 1. (a) SEC chromatograms of the chitosaccharide samples, chitosan polymer and COS mixtures. (b) Thermogravimetric analyses under nitrogen flow of the chitosan and COS preparation. 
undertaken using matrix-assisted Laser Desorption/Ionization (MALDI) for the production of gas phase ionized COS. First, and as expected, the MALDI-TOF analysis of the chitosan polymer did not provide any results in close agreement with the chain length. On the other hand, the MALDI-TOF mass spectrum of the COS mixture is presented in Figure 2 and clearly demonstrates the presence of a chitooligosaccharide distribution. The mass difference between two consecutive signals amounts to $161 \mathrm{u}$ which corresponds to the residual mass of glucosamine, clearly identifying chitooligosaccharides. The spectrum also reveals that the COS mixture is mainly composed by fully deacetylated chitooligosacharides with DP's from 5 to 10 . For the sake of information, it is important to remind here that the COS are detected upon MALDI as sodium-cationized adducts.

\subsection{Direct Chitosaccharide Addition in the "in Vitro" Culture Media of B. elkanii and Soybean Seedlings}

In the first bioassays, the effect of adding chitosaccharides (either the chitosan or the COS preparation) to the in vitro culture media of B. elkanii and soybean plantlets is addressed.

\subsubsection{Effect on B. elkanii Cells Viability}

The viability of $B$. elkanii cells growing in chitosaccharide-amended culture media is significantly modified depending on the structure and concentration of these molecules (Figure 3). At all doses tested, chitosan induced a

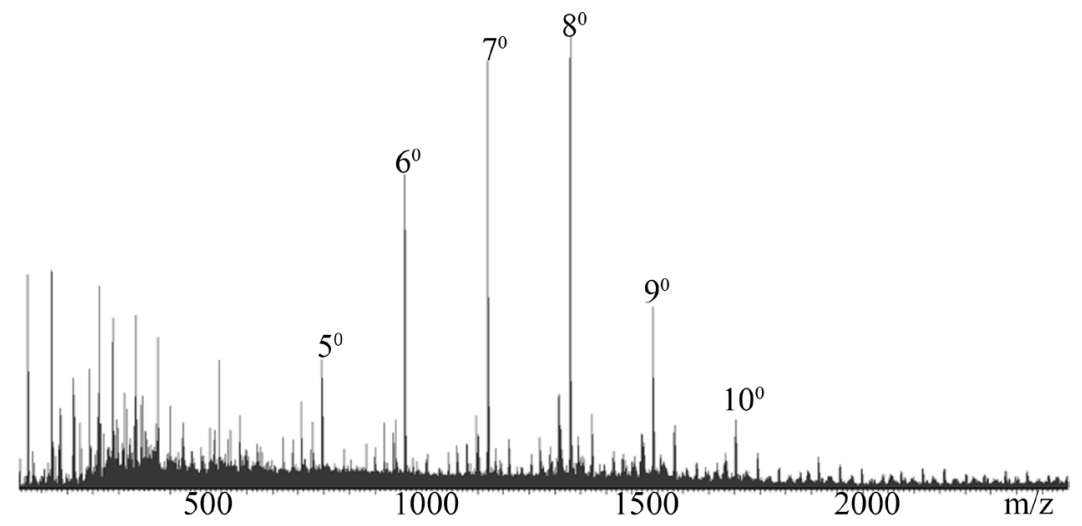

Figure 2. MALDI-TOF MS analysis of the chitooligosaccharide mixture (COS). Identified peaks are labelled as $\mathrm{X}^{\mathrm{Y}}$, where $\mathrm{X}$ indicates degree of polymerization and $\mathrm{Y}$, the number of acetyl groups.

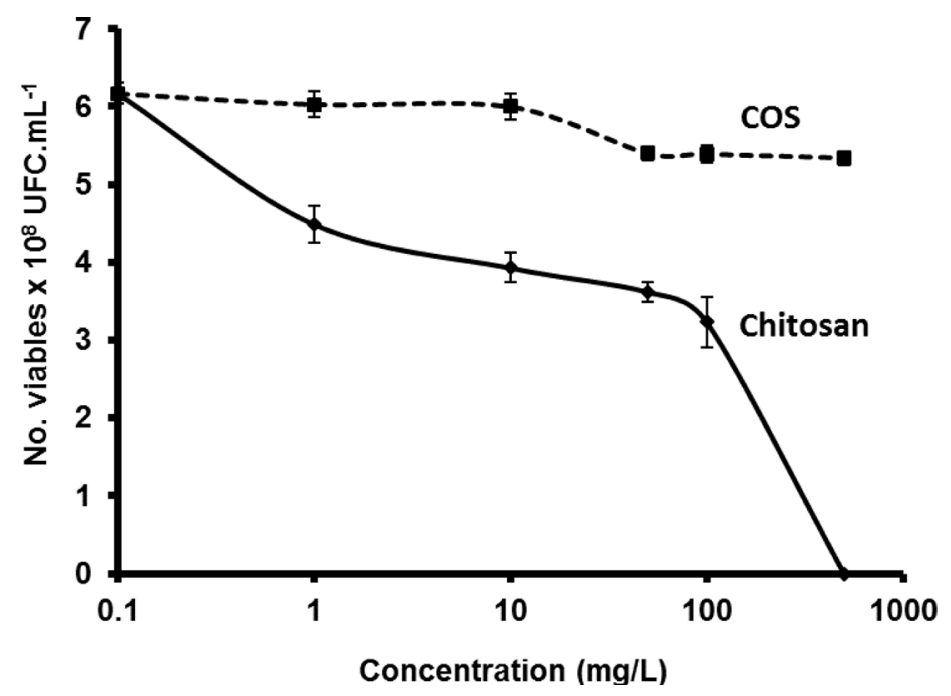

Figure 3. Effect of chitosacharides additions to the culture media on the viability of B. elkanii after 10 days after Petri dish inoculation.Data are mean \pm SE among treatments in the Test of Multiple Rank of Tukey HSD for $\mathrm{p} \leq 0.05$. Chitosan [SE $\left.\mathrm{SE} \overline{\mathrm{x}}=0.23^{*}\right]$ and $\mathrm{COS}[\mathrm{SE} \overline{\mathrm{x}}=0.12 *]$. 
significant reduction of bacteria growth. Actually, the highest doses even cause the complete inhibition of bacteria viability, showing a bactericide behaviour, since the initial bacteria presence is not maintained. However, in presence of COS, B. elkanii viability is only slightly reduced at concentration equal or higher than $50 \mathrm{mg} \cdot \mathrm{L}^{-1}$. The minor inhibition caused by COS is biologically irrelevant, since B. elkanii viability never decreases under the same exponential of CFU valour of the control. Consequently, by reducing chitosaccharides molecular weights, the inhibitory effect on B. elkanii viability is drastically impaired.

\subsubsection{Effect on Soybean Plantlet Nodulation}

The development of nitrogen-fixing nodules in soybean roots is the result of a successful signal exchange with a compatible rhizobacterium. Therefore, the symbiosis effectiveness can be estimated based on the amount of nodules formed on the roots, as well as by following their growth. The number and weight of nodules in roots of soybean plantlets inoculated with B. elkanii and growing in media containing different doses of chitosacharides are then evaluated as a marker of the symbiotic activity (Figure 4). It is important to state that all nodules found in the experiment were effective.

As revealed in Figure 4, the presence of the chitosan preparation, at least in the investigated concentration range, does not impact drastically the symbiotic activity since the number of nodules does not significantly change. Moreover, a minor reduction of the number of nodules is observed when the chitosan concentrations reach above $500 \mathrm{mg} \cdot \mathrm{L}^{-1}$. On the other hand, the total dry mass of nodules by plantlet slightly decreases with increasing chitosan concentration. At concentrations higher than $500 \mathrm{mg} \cdot \mathrm{L}^{-1}$, chitosan drastically hinders the development of soybean nodules resulting in a reduction of 2.5 fold of the dry mass of nodules when compared to untreated plants (control). We could tentatively explain the negative effects observed at higher doses by an enhanced toxic effect of chitosaccharides on B. elkanii and on plant cells. Indeed, induction of plant cell death by high doses of chitosaccharides has been previously reported [21]. Nevertheless, the effect of chitosan remains, in the tested concentration range, quite limited. A different behaviour is then observed when soybean plantlets are growing in media containing the COS preparation. Indeed, increasing the COS concentration results in gradual increases in the number and the dry mass of nodules with both values reaching a plateau at $100 \mathrm{mg} \cdot \mathrm{L}^{-1}$ of COS. At this concentration, the number and mass of nodules are measured four times higher than in the untreated soybean plantlets (control). However, again with increasing concentration, a dramatic decrease in the number and dry mass of the nodules is significantly observed with recorded values at $500 \mathrm{mg} \cdot \mathrm{mL}^{-1}$ similar to the chitosan case.

\subsubsection{Effect on Soybean Seedling Growth}

At the end of the "in vitro" experiments (30 days after B. elkanii inoculation), the vegetative growth parameters of soybean plantlets were evaluated (Figure 5).

Chitosan doses of 50 and $100 \mathrm{mg} \cdot \mathrm{L}^{-1}$ added to the growth medium triggered a significant increment in the number of leaves over the control plantlets. However, at higher concentration $\left(1000 \mathrm{mg} \cdot \mathrm{L}^{-1}\right)$, chitosan significantly reduces all vegetative growth parameters by almost 50\% (Figure 5 left graph).

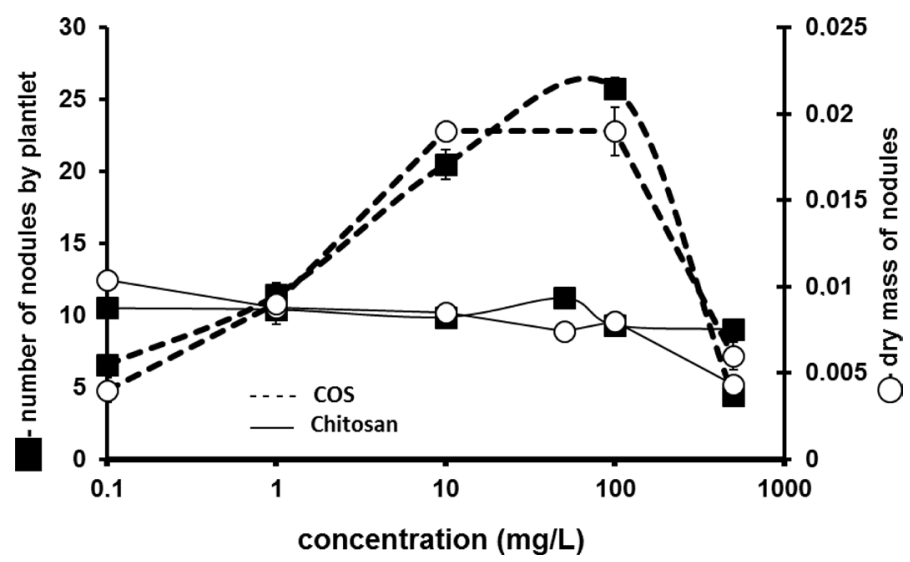

Figure 4. Variation in the number and dry mass of nodules (30 dai) in the roots of soybean plantlets growing in culture media modified by addition of Chitosan [ $\left.\mathrm{SEX}=0.96 *, 0.70^{*}\right]$ and $\operatorname{COS}\left[\mathrm{SEx}=0.001^{*}, 0.01 *\right.$ ], and inoculated with Bradyrhizobium elkanii. Data are mean \pm SE among treatments in the Test of Multiple Rank of Tukey HSD for $\mathrm{p} \leq 0.05$. 
A comparable dose-response pattern is observed in COS amended media (Figure 5 right graph). However, the numbers of leaves in soybean plantlets growing on media containing 50 and $100 \mathrm{mg} \cdot \mathrm{L}^{-1}$ of COS is only partially increased. In addition, COS higher doses $\left(1000 \mathrm{mg} \cdot \mathrm{L}^{-1}\right)$ only slightly affect soybean root growth while other plant growth parameters show no significant differences in relation to control plantlets.

As the perception of chitosan by different plant structures could affect the response of growth and nodulation, an in vivo experiment to test a different mode of application is performed.

\subsubsection{Effect of Foliar Application of Chitosaccharides on Soybean Nodulation and Growth under Pots Conditions}

Under field plot conditions, foliar application of the chitosaccharides preparations on soybean plants also triggers different responses on vegetative growth parameters and nodulation (Table 2). Two concentrations used in the in vitro bioassay were selected for foliar spray application at field, depending on the results in nodulation and growth of seedlings, in order to understand the behaviour of these concentrations with a different application form. For instance, $50 \mathrm{mg} \cdot \mathrm{L}^{-1}$ caused the maximum increase in the nodulation and growth of seedlings with both chitosaccharides, while $500 \mathrm{mg} \cdot \mathrm{L}^{-1}$ caused nodulation reductions and lower values of growth.

When chitosaccharides are applied by foliar spray, chitosan seems to be more effective than COS enhancing soybean nodulation and growth. The number and dry weight of nodules are significantly enhanced by chitosan applications irrespective of the doses tested. Foliar application of COS induces less effective modulating of soybean nodulation. Only the higher COS doses slightly enhance nodule number over control values while the dry weight of the nodules remains unchanged.

In correspondence with an improved nodulation, soybean plants sprayed with chitosan show better growth
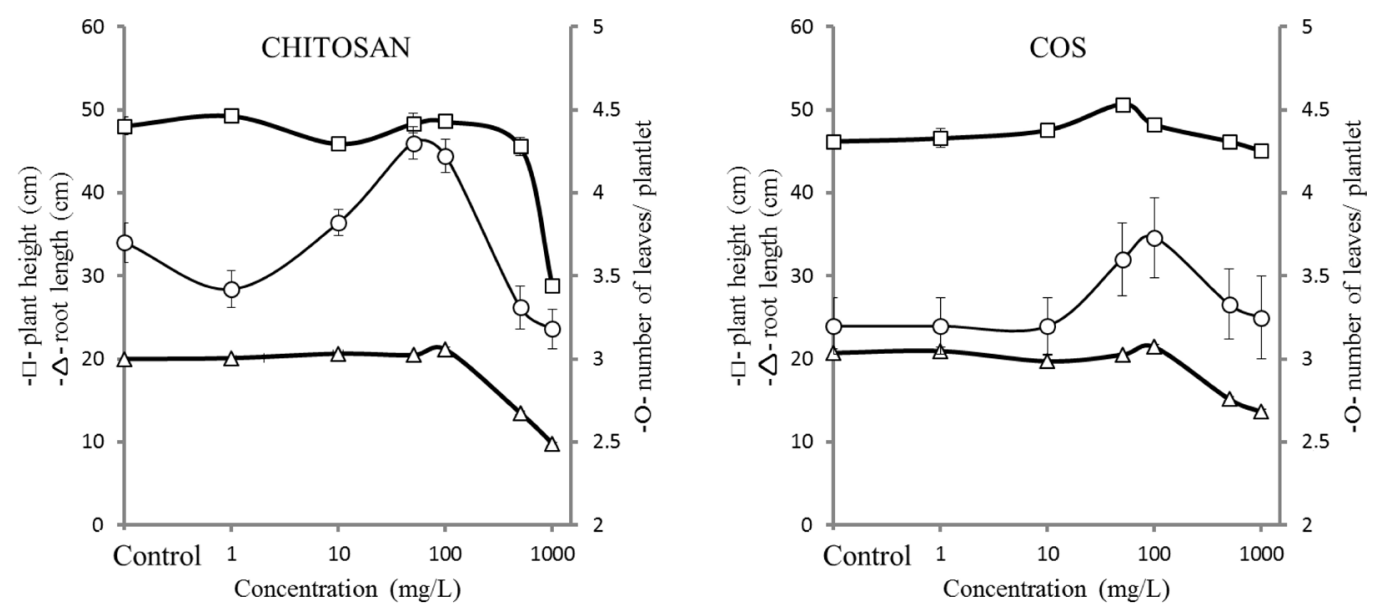

Figure 5. Change in the number of leaves, plant height and root length of soybean plantlets (30 dai) cultured in amedium

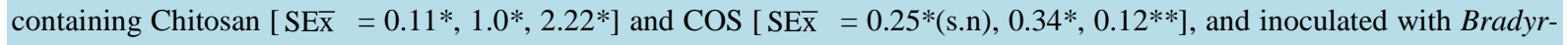
hizobium elkanii. Data are mean $\pm \mathrm{SE}$ among treatments in the Test of Multiple Rank of Tukey HSD for $\mathrm{p} \leq 0.05$.

Table 2. Effect of foliar application of chitosan and COS preparations on the growth and nodulation of soybean plants. Different letters among treatments indicate significant differences in Duncan Test $(\mathrm{p} \leq 0.05)$.

\begin{tabular}{|c|c|c|c|c|c|c|c|}
\hline \multirow{2}{*}{$\begin{array}{l}\text { Treat- } \\
\text { ment }\end{array}$} & \multirow{2}{*}{$\begin{array}{c}\text { Doses } \\
\left(\mu \mathrm{g} \cdot \text { plant }^{-1}\right)\end{array}$} & \multicolumn{2}{|c|}{ Nodulation } & \multicolumn{4}{|c|}{ Plant growth } \\
\hline & & $\begin{array}{c}\text { Number of } \\
\text { nodules }\end{array}$ & $\begin{array}{l}\text { Dry mass } \\
\text { nodules }\end{array}$ & Heights(cm) & $\begin{array}{l}\text { Leaves } \\
\text { (number) }\end{array}$ & $\begin{array}{c}\text { Pods } \\
\text { (number) }\end{array}$ & $\begin{array}{l}\text { Aerial part of the plant } \\
\text { (dry mass) }\end{array}$ \\
\hline \multicolumn{2}{|c|}{ Control } & $16.9 \mathrm{~b}$ & $0.18 \mathrm{~b}$ & $32.7 \mathrm{~b}$ & 29.4 & $31.6 \mathrm{~b}$ & $10.8 \mathrm{~b}$ \\
\hline \multirow{2}{*}{$\cos$} & 75 & $16.1 \mathrm{~b}$ & $0.28 \mathrm{ab}$ & $38.5 \mathrm{~b}$ & 31.4 & $43.8 \mathrm{~b}$ & $13.2 b$ \\
\hline & 750 & $24.8 \mathrm{a}$ & $0.23 \mathrm{~b}$ & $38.1 \mathrm{~b}$ & 31.0 & $38.8 \mathrm{ab}$ & $12.5 \mathrm{~b}$ \\
\hline \multirow{2}{*}{ Chitosa } & 75 & $31.1 \mathrm{a}$ & $0.42 \mathrm{a}$ & $48.0 \mathrm{a}$ & 31.8 & 57.6 a & $15.3 \mathrm{ab}$ \\
\hline & 750 & 25.7 a & $0.41 \mathrm{a}$ & 46.9 a & 34.9 & $59.4 \mathrm{a}$ & $17.5 \mathrm{a}$ \\
\hline \multicolumn{2}{|c|}{$\mathrm{ES} \overline{\mathrm{x}}$} & $1.63^{*}$ & $0.04^{*}$ & $1.43^{*}$ & $1.20 *(\mathrm{~s} . n)$ & $4.02 *$ & $1.04 *$ \\
\hline
\end{tabular}


and yield parameters. The dry weights of the aerial part and plant height as well as the number of pods produced are statistically superior over control plants. No statistical difference is observed in plant growth parameters and yield in plants sprayed with COS, even if the values of some parameters are slightly superior to control plants.

\section{Discussion}

The current work has been focused on the effect of chitosaccharides on the interaction between B. elkanii and soybean. The concentrations and doses of chitosacharides used at work were chosen of previous results of the laboratory and literature [25] [28] [29].

In Figure 4, the results showed that, the direct addition of chitosaccharides to the in vitro culture media of soybean plantlets let to a decrease of the number and the dry mass of nodules in the plants roots with increasing concentration of chitosan, while low molecular weight COS enhance both nodulation parameters at low and moderate concentrations. This result could be partially explained by the non-effect of COS on B. elkanii cell viability (Figure 3) and also by a plausible better "perception" of low molecular weight COS rather than polymeric chitosan by the plant cells. So, chitosaccharide size seems to be critical to modulate soybean nodulation.

The mechanism by which COS can increase nodulation is unknown. However, increased levels of isoflavones in seeds of soybean plants challenged with low acetylated COS preparations have also been reported [30]. Consequently, benefits provoked by COS treatment could also be the result of an indirect effect on the plant metabolism, such as increasing isoflavonoids at root level.

The antimicrobial activity of chitosan polymer on B. elkanii cells (Figure 3) appears determining in the negative effect of this polymer on soybean nodulation "in vitro". It is well known that chitosan inhibits bacterial growth [31] [32], however, the mechanism behind this effect is still not well understood. Usually, it is attributed to the polycationic character of the chitosan polymer at $\mathrm{pH} \leq 6$ where the amino group is positive charged. This polycation can interact with the opposite charges of phospholipids in the bacteria cell wall causing cellular disruption and even cell leakage [32] [33]. In this sense, differences in bacterial cell wall structure seem also relevant since Gram positive bacteria are more susceptible than Gram negative. In presence of chitosan, Gram positive bacteria cell walls are disrupted and broken followed by cell autolysis. Gram negative bacteria are more resistant since only minor retractions of the cell membrane in the presence of chitosan are observed and only higher doses of this biopolymer affect bacterial growth and viability [10] [32]. This could explain why B. elkanii (a Gram negative bacterium) viability is only reduced at chitosan concentrations above $500 \mathrm{mg} \cdot \mathrm{L}^{-1}$ (Figure 3). To our knowledge, this is the first report showing chitosan antimicrobial activity in the Bradyrhizobium genus.

On the other hand, chitosaccharides can induce local and systemic resistance in plants [12] [34]. We have observed activation of defensive enzymes in the roots of soybean plantlets growing in a culture media containing this chitosan polymer (data not shown). A higher activity of these antimicrobial enzymes (at the highest polymer concentrations) could also prevent the entry of the symbiotic bacteria in plant roots tissues, as previously stated by [35] and [36].

Enhanced and inhibited plant growth by chitosan derivatives have been previously reported for some species growing in vitro, as dependent on the concentration and the assayed plant species [37] [38]. In this work, it is demonstrated that the influence of concentration on plant growth is also affected by the molecular weight of the chitosan compound used.

A different response pattern is triggered by foliar spraying, where chitosan seems to be more effective than COS in enhancing soybean nodulation and growth (Table 2). Thus, while the antimicrobial activity of chitosan on B. elkanii cells appears determining on soybean nodulation when added directly in the culture "in vitro" media, it seems to be irrelevant when foliar sprayed on soybean plants. In fact, using this application technique, soybean nodulation is significantly boosted by chitosan.

Previous works in others plant species beyond soybean have reported the closure of plant stomata after foliar spraying of chitosan, dealing with a reduction in water lost by the plant. These authors considered this anti-transpirant effect as the main cause behind the enhanced effect on plant growth by chitosan [28] [39]. This could be, also, the main cause of the increments of height, dry mass of aerial part and of the number of pods found in plants applied with the chitosan polymer.

However, an activation of plant physiology should not be discarded, taking into account that, foliar spraying this polymer type causes rise of chlorophylls content, of phosphorus and nitrogen concentration in leaves and activates nitrate reductase enzyme, among other variables, justifies an activation of the photosynthesis and the intake of nutrients in soybean plants [29] [40]. 
In short, results clearly revealed that, chitosaccharide structure and concentration, as well as the application method, seem to be key-parameters with regards to the modulating activities on soybean nodulation and growth. This result has great importance from a practical point of view since it would allow taking suitable decisions concerning the type of chitosan to be used, the concentration and the way of application in plants, when working with these bioactive polysaccharides in interaction with Bradyrhizobium biofertilizers.

\section{Acknowledgements}

First author wants to thank the financial support to the research included in this publication by the International Foundation for Science (Project F-4446-2F) and the Organization for the Prohibition of Chemical Weapons (OPCW).

\section{References}

[1] Ohyama, T., Minagawa, R., Ishikawa, S., Yamamoto, M., Hung, N.V.P., Ohtake, N., Sueyoshi, K., Sato, T., Nagumo, Y. and Takahashi, Y. (2013) Soybean Seed Production and Nitrogen Nutrition. In: Board, J.E., Ed., A Comprehensive Survey of International Soybean Research-Genetics, Physiology, Agronomy and Nitrogen Relationships, Intech, 2013. http://dx.doi.org/10.5772/52287

[2] Xavier, G., Correia, M., de Aquino, A., Zilli, J. and Rumjanek, N. (2010) The Structural and Functional Biodiversity of Soil: An Interdisciplinary Vision for Conservation Agriculture in Brazil. In: Dion, P., Ed., Soil Biology and Agriculture in the Tropics, Vol. 21, Springer, Berlin Heidelberg, 65-80. http://dx.doi.org/10.1007/978-3-642-05076-3_4

[3] Jensen, E., Peoples, M., Boddey, R., Gresshoff, P., Hauggaard-Nielsen, H.J.R., Alves, B. and Morrison, M. (2012) Legumes for Mitigation of Climate Change and the Provision of Feedstock for Biofuels and Biorefineries. Agronomy for Sustainable Development, 32, 329-364. http://dx.doi.org/10.1007/s13593-011-0056-7

[4] Peoples, M.B., Brockwell, J., Herridge, D.F., Rochester, I.J., Alves, B.J.R., Urquiaga, S., Boddey, R.M., Dakora, F.D. and Bhattarai, S. (2009) The Contributions of Nitrogen-Fixing Crop Legumes to the Productivity of Agricultural Systems. Symbiosis, 48, 1-17. http://dx.doi.org/10.1007/BF03179980

[5] Canfield, D.E., Glazer, A.N. and Falkowski, P.G. (2010) The Evolution and Future of Earth's Nitrogen Cycle. Science, 330, 192-196. http://dx.doi.org/10.1126/science.1186120

[6] Nápoles, M.C., Gómez, G., Costales, D., Freixas, J.A., Guevara, E., Meira, S., González-Anta, G. and Ferreira, A. (2011) Signals in Soybean’s Inoculants. InTech-Open Access Publisher, Ed., Soybean-Biochemistry, Chemistry and Physiology, 323-344.

[7] Salvagiotti, F., Cassman, K.G., Specht, J.E., Walters, D.T., Weiss, A. and Dobermann, A. (2008) Nitrogen Uptake, Fixation and Response to Fertilizer N in Soybeans: A Review. Field Crops Research, 108, 1-13. http://dx.doi.org/10.1016/j.fcr.2008.03.001

[8] Carvalho, G.A., Batista, J.S., Marcelino-Guimaraes, F.C., Nascimento, L.C. and Hungria, M. (2013) Transcriptional Analysis of Genes Involved in Nodulation in Soybean Roots Inoculated with Bradyrhizobium japonicum Strain CPAC 15. BMC Genomics, 14, 153. http://dx.doi.org/10.1186/1471-2164-14-153

[9] Deaker, R., Hartley, E. and Gemell, G. (2012) Conditions Affecting Shelf-Life of Inoculated Legume Seed. Agriculture, 2, 38-51. www.mdpi.com/journal/agriculturedoi:10.3390/agriculture2010038 http://dx.doi.org/10.3390/agriculture2010038

[10] Badawy, M.E.I. and Rabea, E.I. (2011) A Biopolymer Chitosan and Its Derivatives as Promising Antimicrobial Agents against Plant Pathogens and Their Applications in Crop Protection International. Journal of Carbohydrate Chemistry, 2011, Article ID: 460381. http://dx.doi.org/10.1155/2011/460381

[11] Katiyar, D., Hemantaranjan, A., Singh, B. and Bhanu, N. (2014) A Future Perspective in Crop Protection: Chitosan and Its Oligosaccharides. Advances Plants Agriculture Researches, 1, Article ID: 00006.

[12] Falcón-Rodríguez, A.B., Costales, D., Cabrera, J.C. and Martínez-Téllez, M.A. (2011) Chitosan Physic-Chemical Properties Modulate Defense Responses and Resistance in Tobacco Plants against the Oomycete Phytophthora nicotianae. Pesticide Biochemistry and Physiology, 100, 221-228. http://dx.doi.org/10.1016/j.pestbp.2011.04.005

[13] Huang, L., Cheng, X., Liu, C.H., Xing, K., Zhang, J., Sun, G., Li, X. and Chen, X. (2009) Preparation, Characterization, and Antibacterial Activity of Oleic Acid-Grafted Chitosan Oligosaccharide Nanoparticles. Frontiers of Biology in China, 4, 321-327. http://dx.doi.org/10.1007/s11515-009-0027-4

[14] Alfaro-Gutiérrez, I.C., Guerra-Sánchez, M.G., Hernández-Lauzardo, A.N. and Velázquez-del Valle, M.G. (2014) Morphological and Physiological Changes on Rhizopus stolonifer by Effect of Chitosan, Oligochitosan or Essential Oils. Journal of Phytopathology, 162, 11-12. http://dx.doi.org/10.1111/jph.12252 
[15] Se-Kwon, K. (2011) Chitin, Chitosan, Oligosaccharides and Their Derivatives. Biological Activities and Applications. CRC Press Is an Imprint of Taylor \& Francis Group, LLC. 6000 Broken Sound Parkway NW, Suite 300 Boca Raton, FL 33487-2742.

[16] Cooper, J.E. (2007) Early Interactions between Legumes and Rhizobia: Disclosing Complexity in a Molecular Dialogue. Journal of Applied Microbiology, 103, 1355-1365. http://dx.doi.org/10.1111/j.1365-2672.2007.03366.x

[17] Prell, J. and Poole, P. (2006) Metabolic Changes of Rhizobia in Legume Nodules. Trends in Microbiology, 14, 161168. http://dx.doi.org/10.1016/j.tim.2006.02.005

[18] Charron, D., Pingret, J.L., Chabaud, M., Journet, E.P. and Barker, D.G. (2004) Pharmacological Evidence That Multiple Phospholipid Signaling Pathways Link Rhizobium Nodulation Factor Perception in Medicago Truncatula Root Hairs to Intracellular Responses, Including $\mathrm{Ca}^{2+}$ Spiking and Specific ENOD Gene Expression. Plant Physiology, 136, 3582-3593. http://dx.doi.org/10.1104/pp.104.051110

[19] Yin, H., Du, Y. and Dong, Z. (2016) Chitin Oligosaccharide and Chitosan Oligosaccharide: Two Similar but Different Plant Elicitors. Frontiers in Plant Science, 7, 522. http://dx.doi.org/10.3389/fpls.2016.00522

[20] Deakin, W.J. and Broughton, W.J. (2009) Symbiotic Use of Pathogenic Strategies: Rhizobial Protein Secretion Systems. Nature Reviews Microbiology, 7, 312-320. http://dx.doi.org/10.1038/nrmicro2091

[21] Cabrera, J.C., Messiaen, J., Cambier, P. and Van Cutsem, P. (2006) Size, Acetylation and Concentration of Chitooligosaccharide Elicitors Determine the Switch from Defence Involving PAL Activation to Cell Death and Water Peroxide Production in Arabidopsis Cell Suspensions. Physiologia Plantarum, 127, 44-56. http://dx.doi.org/10.1111/j.1399-3054.2006.00677.x

[22] Muzzarelli, R.A.A. (1999) Analytical Biochemistry and Clinical Significance of N-Acetyl- $\beta$-D-Glucosaminidase and Related Enzymes. In: Jollès, P. and Muzzarelli, R.A.A., Eds., Chitin and Chitinases, Birkhauser Verlag, Basel, 235247.

[23] Younes, I. and Rinaudo, M. (2015) Chitin and Chitosan Preparation from Marine Sources. Structure, Properties and Applications. Marine Drugs, 13, 1133-1174. http://dx.doi.org/10.3390/md13031133

[24] Chacón, A., Alemán, R., Barreda, A., Colás, A., Rodríguez, G. and Cardoso, S. (2009) Influencia de la época de siembra sobre el crecimiento y desarrollo de tres cultivares de soya [Glycine max (L.) Merr.]. Centro Agrícola, 36, 3339.

[25] Costales, D., Nápoles, M.C. and Falcón, A.B. (2007) Influencia de oligosacáridos de quitosana y pectina en la interacción simbiótica Soya-Bradyrhizobium. Cuban Journal of Agricultural Science, 41, 175-181.

[26] Mao, S., Shuai, X., Unger, F., Simon, M., Bi, D. and Kissel, T. (2004) The Depolymerization of Chitosan: Effects on Physicochemical and Biological Properties. International Journal of Pharmaceutics, 281, 45-54. http://dx.doi.org/10.1016/j.ijpharm.2004.05.019

[27] Tsao, C.T., Chang, C.H., Lin, Y.Y., Wu, M.F., Han, J.L. and Hsieh, K.H. (2011) Kinetic Study of Acid Depolymerization of Chitosan and Effects of Low Molecular Weight Chitosan on Erythrocyte Rouleaux Formation. Carbohydrate Research, 346, 94-102. http://dx.doi.org/10.1016/j.carres.2010.10.010

[28] Javan, M., Tajbakhsh, M. and Abdollahi Mandoulakani, B. (2013) Effect of Antitranspirants Application on Yield and Yield Components in Soybean (Glycine max L.) under Limited Irrigation. Journal of Applied Biological Sciences, 7, 70-74.

[29] Mondal, M.M.A., Malek, M.A., Puteh, A.B. and Ismail, M.R. (2013) Foliar Aplication of Chitosan on Growth and Yield Attributes of Mugbean (Vigna radiata (L.) Wilczek). Bangladesh Journal of Botany, 42, 179-183. http://dx.doi.org/10.3329/bjb.v42i1.15910

[30] Al-Tawaha, A.M., Seguin, P., Smith, D.L. and Beaulieu, C. (2005) Biotic Elicitors as a Means of Increasing Isoflavone Concentration of Soybean Seeds. Annals of Applied Biology, 146, 303-310. http://dx.doi.org/10.1111/j.1744-7348.2005.040106.x

[31] Moon, J.S., Kim, H.K., Koo, H.C., Joo, Y.S., Nam, H.M., Park, Y.H. and Kang, M.I. (2007) The Antibacterial and Immune Stimulative Effect of Chitosan-Oligosaccharides against Infection by Staphylococcus Aureus Isolated from Bovine Mastitis. Applied Microbiology and Biotechnology, 75, 989-998. http://dx.doi.org/10.1007/s00253-007-0898-8

[32] Raafat, D., Von Bargen, K., Haas, A. and Sahl, H.-G. (2008) Insights into the Mode of Action of Chitosan as an Antibacterial Compound. Applied and Environmental Microbiology, 74, 3764-3773. http://dx.doi.org/10.1128/AEM.00453-08

[33] Liu, H., Du, Y., Wang, X. and Sun, L. (2004) Chitosan Kills Bacteria through Cell Membrane Damage. International Journal of Food Microbiology, 95, 147-155. http://dx.doi.org/10.1016/j.ijfoodmicro.2004.01.022

[34] Thakur, M. and Singh, B.S. (2013) Role of Elicitors in Inducing Resistance in Plants against Pathogen Infection: A Review. International Scholarly Research Notices (ISRN) Biochemistry, 2013, Article ID: 762412. 
http://dx.doi.org/10.1155/2013/762412

[35] Van Brussel, A.A., Tak, T., Boot, K.J. and Kijne, J.W. (2002) Autoregulation of Root Nodule Formation: Signals of Both Symbiotic Partners Studied in a Split-Root System of Vicia sativa Subsp. Nigra. Molecular Plant-Microbe Interactions: MPMI, 15, 341-349. http://dx.doi.org/10.1094/MPMI.2002.15.4.341

[36] Abramovitch, R.B., Anderson, J.C. and Martin, G.B. (2006) Bacterial Elicitation and Evasion of Plant Innate Immunity. Nature Reviews Molecular Cell Biology, 7, 601-611. http://dx.doi.org/10.1038/nrm1984

[37] Ait Barka, E., Eullaffroy, P., Clement, C. and Vernet, G. (2004) Chitosan Improves Development, and Protects Vitis vinifera L. against Botrytis cinerea. Plant Cell Reports, 22, 608-614. http://dx.doi.org/10.1007/s00299-003-0733-3

[38] Sopalun, K., Thammasiri, K. and Ishikawa, K. (2010) Effects of Chitosan as the Growth Stimulator for Grammatophyllum speciosum in Vitro Culture. World Academy of Science, Engineering and Technology, 71, 449-451.

[39] Iriti, M., Picchi, V., Rossoni, M., Gomarasca, S., Ludwig, N., Gargano, M. and Faoro, F. (2009) Chitosan Antitranspirant Activity Due to Abscisic Acid-Dependent Stomatal Closure. Environmental and Experimental Botany Journal, 66, 493-500. http://dx.doi.org/10.1016/j.envexpbot.2009.01.004

[40] Nguyen-Anh, D. (2010) Enhancing Crop Production with Chitosan and Its Derivatives. In: Kim, S.-K., Ed., Chitin, Chitosan, Oligosaccharides and Their Derivatives, CRC Press, Boca Raton, 619-631.

\section{Abbreviations Used}

YEM, yeast extract manitol; NFs, nodulation factors; dai, days after inoculations; SEC, Size-exclusion chromatography; COS, chitooligosaccharides

Submit or recommend next manuscript to SCIRP and we will provide best service for you:

Accepting pre-submission inquiries through Email, Facebook, Linkedin, Twitter, etc

A wide selection of journals (inclusive of 9 subjects, more than 200 journals)

Providing a 24-hour high-quality service

User-friendly online submission system

Fair and swift peer-review system

Efficient typesetting and proofreading procedure

Display of the result of downloads and visits, as well as the number of cited articles

Maximum dissemination of your research work

Submit your manuscript at: http://papersubmission.scirp.org/ 